\title{
A Somogy megyei Kisgyalán faluközössége által kedvelt népdalok és magyar nóták az elmúlt száz esztendőben
}

\author{
LANSZKI-SZÉLES GABRIELLA
}

\author{
Szent István Egyetem Kaposvári Campus, H-7401 Kaposvár, Pf.: 16., \\ e-mail: Lanszki-Szeles.Gabriella.Edit@szie.hu
}

\begin{abstract}
LANSZKI-SZÉLES, G.: Folk songs and Hungarian songs loved by the community of Kisgyalán in Somogy county (Hungary). Abstract: Respect for traditions is still consciousness and character-forming, which is reinforced by folk songs and Hungarian songs. What is being said is easier and more beautiful with the help of the thoughts expressed by their lyrics In order to study this, I recorded everyone's most favored song, folk song, and sometimes ballad in my hometown, Kisgyalán. From a methodological point of view, different versions and variations of folk songs and Hungarian songs were searched. The favored songs varied based on the inhabitant's occupation, character, appearance, different qualities, and also on their different abilities and orientations. Different songs were sung at a wedding, at work, at school, or even during drinking. What one wanted to let others know, s/he told them what was on his or her mind by singing. During the recall of the songs, long-unmentioned images of life also came to life.
\end{abstract}

Keywords: village community, wedding, outlaw song, ballad, hired song, military song, tradition, celebration

„Száll a madár, ágrul ágra, Száll az ének, szájrul szájra;" ARANY JÁNOS mindenki által ismert és szállóigévé vált mondata mottóként kívánkozik ide. Mert miközben ez a két sor egy természeti hasonlattal élve az ének emberek közötti tovaterjedéséről szól, amellett szinte példaként idézi fel a népdalokra oly jellemző hangzásvilágot - a nyelv csengését - a verssorok végén található páros rímnek köszönhetően. Igen, az énekszó összetart.

Talán nincs is bensőségesebb érzés, mint a szülöföldhöz, a saját településünkhöz való kötődés. Mert legyenek azok életfordulók, vallási események, vagy akár a közösség egyéb kulturális, például a helyi színjátszással kapcsolatos szíves visszaemlékezések, ezekből mindig kiderül, hogy milyen szoros és mennyire fontos az itt élő emberek számára az egymásra való odafigyelés, az összetartozás érzése. A hagyományok tisztelete ma is megkülönböztetett emberi magatartás, mert tudat és jellemformáló, amit a népdalok és a magyar nóták csodálatos dallamvilágukkal erősítenek, ráadásul a szövegük által megfogalmazott gondolatok segítségével, könnyebben, szebben kifejezhető a mondandó. Ezért a téma időszerüsége ma sem veszített fényéből, és fontossága éppolyan egy közösség számára ma is, mint akár évszázadokkal ezelőtt. A falu összejövetelein a hagyományőrzés révén a dalkincsnek továbbra is fontos szerepe maradt.

Ennek tanulmányozása érdekében szülöfalumban, Kisgyalánban jegyeztem le, hogy kinek mi volt a legkedveltebb nótája, népdala, esetenként balladája. Nagy előnyt jelentett számomra, hogy én is ebbe a közösségbe tartozom, ami egy kulturális tájegység része. Módszertani szempontból talán nem érdektelen, hogy éppen ezért az eldalolt népdalokra, magyar nótákra rákerestem, hogy azoknak milyen változatai léteznek, és az egyes variációk miben térnek el egymástól. Az emberek - foglalkozásuk, jellemük, küllemük, eltérő tulajdonságaik alapján - nótái is eltérők, éppen másmás adottságaiknak, orientációjuknak köszönhetően. $\mathrm{Az}$ emberek mást énekelnek a lakodalomban, munka közben, iskolában, vagy akár poharazgatás közben. Amit tudatni akart az ember a környezetével, hát kiénekelte magából, üzenve ezzel másoknak, hogy mostanság mi foglalkoztatja gondolatvilágát. Nem meglepő, de érdekes tapasztalat, hogy a dalok felidézése során, rég nem emlegetett életképek is felelevenedtek.

Az emlékezet szárnyán az emberek lelkivilágát tükröző dalokat az 1800-as évek második felében született idős gyaláni ${ }^{1}$ emberek által elénekelt régi népdaloktól, balladáktól kezdve áll módunkban visszaidézni, amiket Varga Gyula tanító jegyzett le.

Néprajzi funkciójuk szerint alkalomhoz kötött, vagy alkalomhoz nem kötődő dallamok hangzottak el. A fő szempont, ami szerint a gyüjtést végeztem, hogy mikor, kik, miért, és hol énekelték, és adták át egymásnak a dalok ismeretét. A miértre helyezve a hangsúlyt, mert a danuló egyéniségé, lelkülete határozta meg, hogy mit dalol, mit közvetít közössége felé. Bizony tudta mindenki (a falu lakossága) hogy kiknek van a legszebb hangjuk: „úgy danút mint a sárgarigó, ujjan szép hangja volt" - hangzott a dicséret nem egy esetben. „A Sanyi rágyújtott a nótára, a tanító is kíváncsi volt, a mi fejünk meg bevette. Örzsike idejében (1930-as évek) a lányok mentek vasárnap karöltve az utcán és danútak. Nótát kezdeni nem tudnak Bönci néni² tud."

A falu közösségén keresztül szeretném megismertetni, a felidézett emlékekkel, amely emlékek ma is bizonyítják, miért pont az a dal hangzott el az adott pillanatban. Ezek az énekek ma is ünnepi alkalmakkor elhangzanak, azonban már hagyományőrzés révén kórusban. Bóna Lászlóné Széles Rózsa nagynéném (szül.: 1930), valamint Csima Lajosné Vörös Erzsébet (szül.: 1940) segítségével történt a dalok, és a hozzájuk tartozó történetek lejegyzése, amit ők már korábban az asszonykórus számára is elénekeltek, amelynek tagjai voltak. A választásom oka az volt, hogy tudatában voltam, náluk szebben és több dalt nem énekel el senki a kérésemre.

1 1908-ig Gyalán, azt követően Kisgyalán.

2 Csima Lajosné szíves közlése. 
Vikár Béla ${ }^{3}$ (szül.: 1859) a régióhoz tartozó Hetes község szülötte, 1906-ban kiadott A Magyar Népköltés Remekei című művében írja: „A kevésbé dalos népfia, ha faggatjuk nóták iránt, szívesen igazít el a helyes czímre, a nótafákhoz, hogy ő maga ezen az úton szabaduljon a dalmondásnak rá nézve inkább feszélyező kötelességétöl. (...) Az igazi nótafa ellenben nem igen kéreti magát. Örül, ha dalolhat. Némelyiknek dalkészlete igazán bámulatos, ki nem fogy reggeltöl estig. S a régi hagyományokat, melyeket gyakran szüleiktöl vagy a családnak valamely más tagjától tanultak meg, szintúgy, mint a vidékükön dívó új vagy régiböl fölelevenített dalokat mindig ők tudják legjobban. (...) Felhalmozzák önmagukban a családi örökségként átvett vagy máshonnét összehordott dalkincseket. Így mindenik egy-egy kiadatlan, élö népköltési gyüjtemény." Bóna Lászlóné és Csima Lajosné is igazi nótafák, Vikár Béla szavai szintúgy igazak rájuk is.

Kisgyalán örzi hagyományait, szerencsére nem úgy tűnik, hogy a feledés homályába veszne az itt fellelhető dalkincs. A helyi asszonyok most is gyűjtik az idősebbektől a népdalokat, magyar nótákat.

„A népdal szorosan és közvetlenül kapcsolódik a paraszti falusi élet valóságához. A mindennapi munka és a gondok apró részletei, környezeti tárgyai, természeti jelenségei kerülnek be a dalokba valódi vagy átvitt jelentéssel. A népieskedő magyar nóta a mindennapi munkát és életet kívülröl, idealizálva szemléli. A nótabeli környezet anyagi gondoktól nem háborgatott középrendü birtokosokra vall. (...) A mindenkori fennálló társadalmi renddel kapcsolatosan közvetve vagy közvetlenül mind a három ${ }^{4}$ müfaj állást foglal. A népdal tartalma és társadalmi-müfaji szerepe szerint tiltakozik, lázad, panaszkodik vagy éppen helyesel, a magyar nóta nem ilyen nyilt és egyértelmü." 5

A Hungarikum ${ }^{6}$ Bizottság 2017. március 21. napján a magyar nemzeti értékekről és a hungarikumokról szóló 2012. évi XXX. törvény 12.§ (2) alapján - hungarikummá nyilvánította a Kodály-módszer elnevezésű értéket, mivel az felkerült az UNESCO Szellemi Kulturális Örökség Jó Megőrzési Gyakorlatok Jegyzékébe.

„Kodály Zoltán az 1920-as évek második felében (...) a magyar népzenére támaszkodó gyermekkari müveinek nagy sorozatával intenzíven kezdett foglalkozni a zeneoktatás reformjával. (...) A kóruszene egyetlen és mindenki által birtokolt hangszere az énekhang. Kodály és tanítványai úgy látták, hogy a nemzetnevelés szolgálatába állitott énekhang számára a magyar vokális népzenei hagyomány, a magyar népdal biztosítja a legmeghatá-

3 Az édesapja Vikár János, akinek édesanyja, Both Katalin, Bod Péter leszármazottja, mint ahogy Arany János édesapja is. Vikárkutató | Vikár Béla életútja Majorné Bániczki Julianna Letöltés ideje: 2020.03.23.

4 A harmadik a sláger.

5 Katona I. 2002: 38.

6 A magyar nemzeti értékekröl és a hungarikumokról szóló 2012. évi XXX. Törvény pontosan körül határolja a hungarikum fogalmát. Eszerint a hungarikum: Gyüjtőfogalom, amely egységes osztályozási, besorolási és nyilvántartási rendszerben olyan megkülönböztetésü, kiemelésre méltó értéket jelöl, amely a magyarságra jellemző tulajdonságával, egyediségével, különlegességével és minőségével a magyarság csúcsteljesítménye. rozóbb forrást. A Kodály, Bartók és követőik által gyüjtött népdalkincs megfelelö alapot ad nemcsak a zenei ismeretek elsajátításához, de a gyermekjátékok révén a gyermekek életkorának megfelelő kulturális élmények befogadásához is, miközben a felnőttek népdala a teljes őshazai, illetve a nyugat-európai zenetörténet emlékeit is magában hordozza. (...) Kodály Zoltán zenepedagógia koncepciója a magyar népzenei hagyományra épül."7

A népdal nem vétetett fel még önállóan a Hungarikumok Gyűjteményébe. A magyar betyárköltészet a Hungarikum Bizottság döntése alapján a Magyar Értéktárba tartozik 2019 novembere óta. Az indok: a betyárköltészet közel 200 éves múltra tekint vissza és hozzájárult a magyar virtus eszmei tartalmának fennmaradásához. ${ }^{8}$

Vargyas (1974) nyomán mi is feltehetjük a kérdést, hogy: „Mi a népdal? Egy népnek a műalkotásokkal azonos esztétikai szinten megfogalmazott történelme, hagyománya és jelenléte az általános nemzeti tudatban, ha úgy tetszik, a kulturális közéletben, a jelen közgondolkozásában." A műalkotások, Bartók és Kodály remekmüvei megváltozott funkcióval, pódiumra és színpadra állítva őrzik népzenénket.

A klasszikus magyar nóta a Hungarikum törvény 114/2013. (IV. 16.) felterjesztésével és elbírálása által került a Hungarikumok Gyűjteményébe. „A nóta nagy hatással volt a századforduló kulturális és társadalmi életére, hozzájárult ahhoz, hogy a magyar nyelv lassan és nagy biztossággal kiszorította az idegen szavakat az általános nyelvhasználatból. Napjainkban a hazánkba érkező külföldiek is szívesen hallgatják."9

A 100 tagú cigányzenekar világhírü múvészi és hagyományőrző gyakorlata révén került be a Hungarikumok Gyűjteményébe, 2014. március 18-tól jogosult a hungarikum kitüntető cím használatára.

Ujváry Zoltán írja: „Kutatásaimban nem kevés szerepe volt annak az aggodalomnak is, amelyet az utóbbi egy-két évtizedben a hagyományok pusztulása miatt éreznek a néprajz kutatói. Voltaképpen már majd csaknem száz éve hangoztatják a gyüjtők a népköltészet, a népszokások, hiedelmek, stb. megmentésének huszonnegyedik óráját. A közelmúltban a népi kultúra iránti soha eddig nem tapasztalt - a társadalom legkülönbözőbb rétegeit magába foglaló - érdeklődés a népköltészet, a népdalok, a népzene elötérbe állítását, a gyüjtések, a kutatások kiterjedését, valóságos mozgalmát eredményezte. A népdalkiadványok nagy száma lát napvilágot, szakképzett és önkéntes gyüjtők százával, ezrével jegyeznek le népdalokat, különböző intézmények, kommunikációs fórumok tüzik müsorukra, elöadásokra és versenyekre a népdalokat és a népballadákat. Ennek a mozgalomnak a tudományos és a közmüvelödési jelentösége szinte felbecsülhetetlen. Tudományos szempontból azonban az is megállapítható, hogy a népdalanyag egyre inkább nivellálódik,

\footnotetext{
7 http://www.hungarikum.hu/hu/content/kodály-módszer Letöltés ideje 2019.12.13.

8 Kormányzat - Agrárminisztérium - Hírek Letöltés ideje 2019.12.13

9 Klasszikus magyar nóta | Hungarikumok Gyűjteménye Letöltés ideje 2019.12.13
} 
s a táji, területi jellegzetességek lassan elmosódnak. Ennek számos oka van. Föltétlenül hangsúlyoznunk kell, hogy az idősebb generáció távozásával azok a „kuriózumok” tünnek el, amelyek erösen rányomták bélyegüket egy-egy terület népdalkultúrájára. Úgy tünik, olyan alapanyag marad fenn, amely közkinccsé válva a társadalomban vertikálisan és területileg horizontálisan egyaránt általános lesz." 10

Ezt bizonyítja mikor is a 10 és 80 éves egyszerre, ugyanazon szöveggel fakadt dalra az indító mondatot követően, a továbbiakban visszatérek rá.

Elsőként Varga Gyula tanító jegyezte le az 1950es években, a legrégebbi népdalokat számunkra (kisgyalániaknak):11.,„A községben egy öregember, Jánosi István (szül.: 1870-es évek), aki 4 éves korától kezdve 70 éven át pásztorkodott. Tizenegyen voltak testvérek. Apja mellett kezdte a pásztorkodást. Föleg disznópásztor kanász volt. (...) Fiatal korában furulyázott, citerázott, hegedült. A vele való találkozáskor már 85 éves volt, hangja fakó bizonytalan a dallamközlésre. Ezért ezeket lekottázni már nem igen lehetett. Pedig tudott néhány valóban régi népdalt." Ezek közül néhánynak a feljegyzett szövege:

Mikor Kisbogáton juhász voltam,

Én egy kicsit elaludtam.

A birkáim elszéledtek,

Lucernába belementek.

Harminc darab is elpuffadt. ${ }^{12}$

Énrajtam mingyárt kiadtak.

Osztopáni öregbíró.

Az akasztófára való,

Az állta nékem utamat,

Elvette a birkáimat.

A foglalkozásdalok, pásztordalok közé tartozik ez a népdal.

„A pásztorok egyik legősibb hazája Somogy - az egykori királyi kanászok földje - melyröl Árpád-házi okleveleink is említést tesznek. Különösen a kanászok foglaltak el rangos helyet a pásztortársadalomban (lásd: zselici kanászfalvak). (...) Somogyot régóta úgy ismerik, mint a betyárok hazáját. A nép ezeket a társadalom perifériájára szorult elnyomottakat - gyakori esetben - csavargó életet élő ellenállókat megszépítő szándékkal vette körül, illetve foglalta dalaiba, így keletkezett Somogyban is ezer számra lírai-epikai dal, betyártörténet. (...) A somogyi embereknek - különösen a pásztoroknak - a betyárok iránt érzett megbecsülése szinte természetes volt. Bizonyos okok miatt olykor betyárrá kellett lennie a pásztorembernek. Az is előfordult, hogy a betyárság feladása után pásztorrá lett az ebbe az életformába beleunt bujdosó, vagy ha éppen megkegyelmezett számára a hatalom. Erröl az akár valós, akár képzelt eseményröl több balladánk is szól, pl. Juhász András esete az osztopáni Vörös bí-

10 Gömöri népdalok és népballadák / Ujváry Zoltán. Letöltés ideje:2019.12.15.

11 Ezeket az elsárgult gépelt, illetve fénymásolt oldalakat sokan ma is őrzik.

12 Felfúvódott, betegség, amelybe a birkák elpusztulhatnak, ha sok friss zöld lucernát fogyasztanak. róval. Itt meg kell jegyeznünk azt, hogy majdnem minden esetben két szöveg összeénekléséröl van szó, ami nem sikerülhetett egyik adatközlönk énekénél sem, mert eltérő dallamról, de föleg eltérő szótagszámú szövegekröl van szó. (...) A törés annál a szövegrésznél fordul elő, amikor Juhász András az osztopáni bíróhoz ér. Ennek okát abban látjuk, hogy tulajdonképpen egy pásztordalról és egy betyárballadáról van szó, amelyek - az azonos személyt megéneklö tartalom miatt - egynek tüntek a nép képzeletében, és egybe is akarják mondani." ${ }^{3}$ Jánosi István kisgyaláni lakos is ugyanezzel a töréssel énekelte el.

Az osztopáni Vörös bíró még az 1990-es évek végén is sokszor elhangzott a háztáji gazdaságban folyó munkák közben, amit az 1929-ben született Édesapám is gyakran elénekelt:

Arra alá dörög az ég javába'

Beleütött a rigói csárdába.

Ég a csárda, nem szól benne a cimbalom,

Más vidéken lakik az én galambom.

Onnan alul jön egy öreg hintó,

Benne ül az öreg szolgabíró.

Bíró uram legyen olyan szíves,

Most írjon fel, most vagyok húsz éves.

A katonai sorozások mindig fontos eseménynek számítottak, ez a népdal korábbi évtizedekben énekelt, ezt követte az a népdal amelyben már a legényeket más faluba vitték „feírni” (közlését ld. alább). $\mathrm{Az}$ alábbi régi nótákat Csima Istvánné énekelte: Megfonyom a korbácsomat tizennyolc szálra,

Ráverem a feleségem gyönge hátára. Addig ütöm, míg a karom elfárad, Megállj kedves feleségem megbánod.

Szombat este kérdi tőlem az Anyám: Szereted-e lányom az uradat igatán? Nem szeretem, siratom a lányságom, Siratom is, míg élek a világon.

Szombat este ismét kérdi tőlem az Anyám:

Szereted-e lányom az uradat igatán?

Ha idáig megelégedtem vele,

Ezután is párja leszek örökre.

Édesanyám mondta nékem,

Minek a szerető nékem.

De én anyám azt feleltem,

Gyötör anyám a szerelem.

„A népköltészet legnépesebb családját alkotják szerelmi dalaink, (...) Ezek azok a dalok, amelyeket országosan is, Somogyban is legszívesebben énekeltek és több helyen ma is használnak (ellentétben pl. a klasszikus balladákkal, amelyekből feltünően sokat tudnak, de nem éneklik.) Majdnem kizárólag új stílusú dallamokra éneklik ezeket a szövegeket, amelyek az

13 Együd Á. 1975: 391. 
őszinte szerelemröl, a bánatos érzésekröl, a szemrehányásról, a kiábrándulásról, évődő incselkedésről stb. szólnak. Ezek a dalok bőséges tárházai a természeti képeknek és a szimbólumoknak is."14 Szabó Elek és felesége nótái:

\section{Betyár nóta}

Kaposvári urak huszonnégyen vannak, Mind a huszonnégyen rólam tanakodnak.

A huszonötödik a nevemet diktálja,

Vitéz kapitány úr a nevemet írja.

Hallottad-e hírét a kaposi fegyháznak?

Hát annak a híres somogyi betyárnak?

Hallottam, hallottam szenvedtem is benne,

Verje meg az Isten, aki építtette.

Kaposvári fegyház nyolcsoros ablaka, ${ }^{15}$

Szegény édesanyám sírva jár alatta.

Ne sírj édesanyám, így kell annak lenni, Minden jó családban kell egy rossznak lenni.

Imádkoznám, de nem tudok hiába,

Nem jártam én soha az oskolába.

Édesanyám tanított volna rája,

Régesrégen temető a hazája.

Édesanyám ki a legény, ha én nem?

Ki fésüli fel a haját, ha én nem?

Fölfésülöm bársonyszínű hajamat

Legény vagyok most élem világomat.

A gyaláni faluvégen,

Három akasztófa készen.

Nem készült az másnak egye-egyebeknek,

Öreg bíró esküdt embereknek.

„Ezeket a régi népdalokat ma már néhol, lakodalmakban, hajnal felé dúdoljak az öregemberek. A dallamokat tisztán felfogni igen nehéz, mert a régi öregeknek is bizonytalan a hallása." - írta Varga Gyula az 1950-es években.

Jaj de széles, jaj de hosszú ez az út, Kire ez a kilenc betyár elindult.

Kire ez a kilenc betyár elindult,

Szép csárdásné udvarába befordult.

Adjon Isten szép csárdásné jóestét, Adjon Isten betyár urak szerencsét.

Ne kívánjon betyároknak szerencsét,

Még az éjjel kés ontja ki a vérét.

Rézi Lányom szaladj le a pincébe,

Hozzál jó bort az aranyos iccébe.

Nem kell nékem szép csaplárné jó bora,

Még az éjjel piros vérét kiadja.

Kocsmárosné kiszaladt a kiskertbe, Feltekintett a csillagos egekbe.

Jaj Istenem vedd hozzád a lelkemet, Még az éjjel föld issza a véremet.

14 Együd Á. 1975: 396

15 Valóban kétszer nyolcsoros az akkori fegyház ablaka.
A gyaláni haranglábfa, de magos,

Rá van írva babám neve, de csínos.

Arra mentem, el akartam olvasni,

Csalfa szemem nem tudott rá vigyázni.

Édes tejet nem adtam a madárnak, Jó éjszakát nem mondtam a babámnak. Az sem mondott nekem jó éjszakát, Megcsókoltuk egymás piros orcáját.

Vasárnapig nem kapok szeretőt, Felszántatom a gyaláni temetőt. Belevetem magamat egy virágnak, Ki megszeret, majd leszakít magának.

Ennek a kislánynak hosszú a köténye, Mondtam az anyjának vágjon le belőle. Azt mondta az anyja, nem vág le belöle, Vagy előbb, vagy utóbb asszony lesz belöle.

Nincsen olyan híres gulyás,

Mint a kisgyaláni gulyás.

Van gulyája, van ménese,

Gulyaménes legelője.

„Az érzelmi túlzások természeti kerete, a bánat ábrázolása jóval árnyaltabb, természetközelibb és egyben túlzóbb is, népi líránk tehát inkább bánat-, mint öröm centrikus, továbbá az irodalmi lírához képest bizonyos régiesség és általános vonások jellemzik. A lírai hős individualizációja még nem teljesedett ki: a bánat sújtotta énekes is névtelen, név és személy szerint senkire nem lehet ráismerni, épp ezért hasonló helyzetekben mindenki magáénak érezheti ezeket a dalokat,

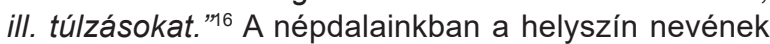
megnevezése is fontos, a Rigó csárda, a gyaláni haranglábfa, amelyek már az óta rég lebontásra kerültek, az emlékezet is a legtöbbröl haloványan él, a népdalok azonban megőrizték. ${ }^{17}$ Főként azok számára, akik már nem is láthattuk, esetleg páran még tudjuk kinek a háza építése során használták fel darabjait például a haranglábnak. Érdekesnek találom, hogyha falun belül történt az újra felhasználása az építőanyagnak, lényegesnek tartja mindenki továbbadni, kérdezés nélkül, hogy mit építettek a lebontott épületből vagy építményböl.

Fekete István a Ballagó idő címü könyvében, helyszínként megörökítette a gyalániak számára az I. világháborúról: „(...) a bevonuló újoncok minden aggodalom nélkül énekelhették, hogy: 'A gyaláni kikötőben áll egy hadihajó', ami nemcsak nóta volt, de még mesének is elképzelhetetlen, hiszen a gyaláni árok másfél méter széles volt, és térdig érő vizében még „fürödni”

16 Katona I. 2002: 219.

17 Greksa Zsuzsanna természetvédelemi mérnök, saját települése homokmégyi népdal helyszínét az I. katonai térképen (1782-1785) tudta beazonosítani. Az első sorban egyből kiderül, hogyan lehet eljutni Alsómégyre. Az aszfaltozott út még nem létezett, de északi és déli irányban volt földes út. Ebböl arra is lehet következtetni, hogy milyen régi a népdal. „Alsómégyre két úton köll bejárni, De szeretnék a rózsámhoz eljárni". 
sem volt érdemes. (...) A gyaláni árok a göllei szölők alatt folyik el, ..." 18

Ezt a katonadalt még Bartók Béla gyűjtötte 1906ban, Bégyulai kikötőbe megállt a gőzhajó kezdetű szöveggel. Mindegyik település, hogy sajátjának érezze az adott dalt előszeretettel illesztette be saját községe nevét a szövegbe, akkor is, ha ez a valósághoz képest igen nagy költői szabadságot feltételezett.

Az I. világháborútól a II. világháború felé haladva még a népdaloké a vezető szerep a magyar nótákéval szemben. Szintén népdal, ami a katonadalok közé sorolandó:
Az igali Koronára süt a nap,
Megjöttek a vizitáló nagyurak.
Vizitálnak engemet, beírják a nevemet,
Beírják a nevemet, a nagykönyvbe,
A záporeső se mossa ki belőle.

A katonai sorozások alkalmával énekelték ezt a legények. Az eseményt megörökítendő fényképek is készültek a regrutákról, a besorozott legényekröl. Öket látjuk az 1. és a 2. ábrán ${ }^{19} 1938$-ban és 1940-ben, Büssüben, a szomszéd községben. Megjegyzem, a büssüi legényeket szintén Igalban sorozták.

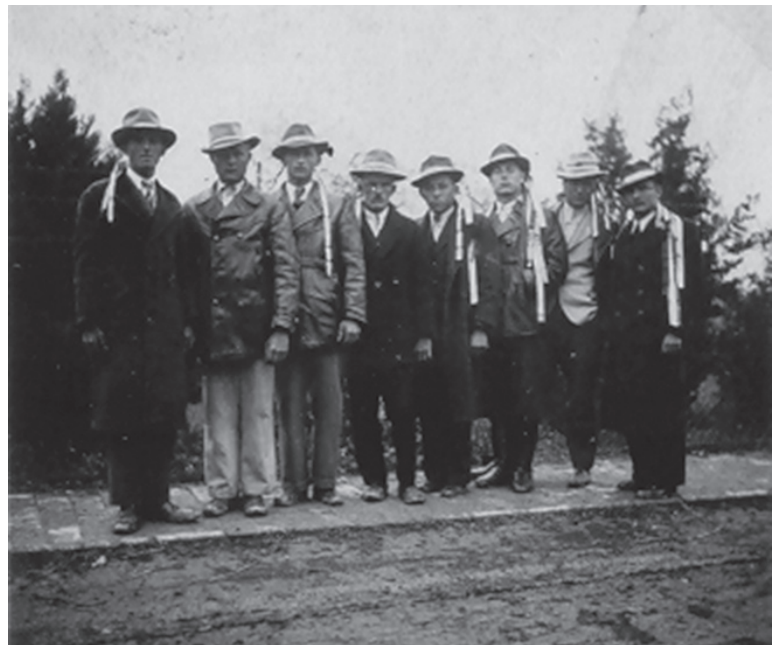

1. ábra. Regruták (Büssü 1938).

A fotókat 2010-ben megmutatva Kisgyalánban, a nagynéném abban a pillanatban dalolni kezdte ezt a népdalt. Örömömet csak fokozta, hogy az akkor a Kaposvári Alapfokú Művészeti Iskolába járó, néptáncoló fiam - aki 1999-ben született - rögtön bekapcsolódott az éneklésbe. Jó volt hallani, hogy a hetvenévnyi kor-

18 „És ki gondolta volna, hogy valamikor ezekről a „dolgokról”, ezekről a drága és borzongatóan szép emlékekröl én valamikor a szigligeti Alkotóházban írok majd, amely akkor még Esterházy-kastély volt, és elképzelhetetlenül nem „alkotóház”, ahol kicsit szomorú örömmel húzom az emlékezés gereblyéjét, hogy összekotorjam a múlt bánatának és örömének virágos, de hervadó és szomorúan illatos szénáját?" - folytatja Fekete István. Ö is visszautal az Esterházy-kastélyra, amiből a szigligeti Alkotóház lett, bár itt annak a valószínűtlenségre utal, hogy kastély alkotóházzá válhatott.

19 Horváth György által rendelkezésre bocsájtott fényképek.

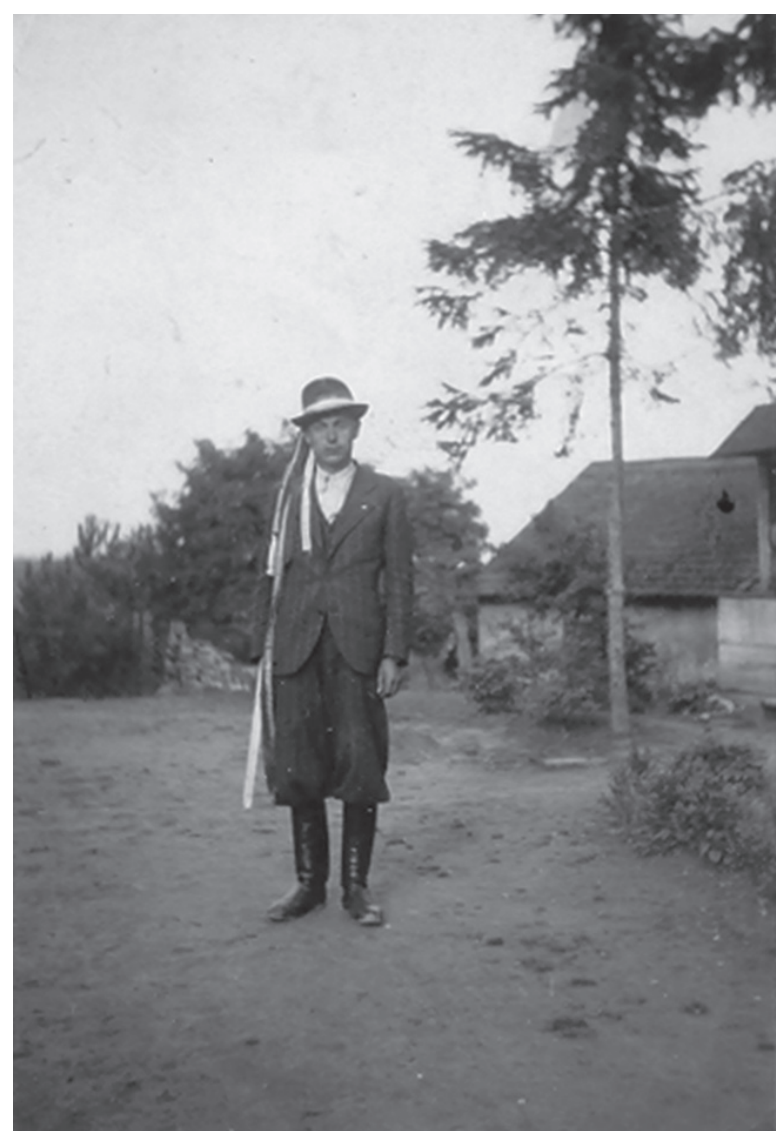

2. ábra. Besorozott legény (Büssü 1940).

különbség ellenére 'közös nevezőn' vannak. A hagyományőrzés révén a népdalkincs így válik maradandóvá a mai nemzedék számára, nekem pedig örök élmény, ahogy spontán együtt kezdték el harsogni a dalt. ${ }^{20}$

A népdal első sorából értesülünk a sorozás helyszínéről, az igali Koronáról, amely ma panzióként működik, nevét máig megtartotta. Együd Árpád gyűjtéséből származik, az igali legények által énekelt dal (Szíjártó Pál, szül: 1895, lgal):

Az igali nagy kocsmába ég a lámpavilág,

Az igali legényeket abba vizitálják.

Engömet is oda várnak, nevemet kiáltják,

De sok szölke, barna kislány siratgatja a babáját.

A Kisgyalán és Igal közötti távolság $18 \mathrm{~km}$. „Kocsin község dolgában vitték a legényeket a sorozásra Igalba. Estefelé meggyüttek a legények énekelve, könnyen bevette a fejem a nótát." - emlékezett vissza nagynéném, Bóna Lászlóné.

Ahol a legények az 1940-as években leszálltak a kocsiról, Szipliék kocsmája volt. A szemközti oldalon két házzal odébb lakó Széles József, pedig méltán da-

20 Hasonló hatást váltott ki az a dal is: „Vénasszonyért nem kár volna, ha pokolban láncon lógna, olyan ráncos annak börre, ..." -amit a tíz éves fiam a nagynéném 80 . születésnapján énekelt el, a „na énekeld el, mit tanultált," szokványos szülöi unszolásra. Kicsit meghökkentünk a választott dalon, de aztán mindenki elnevette magát. 
lolhatta, hiszen a falu végén lakott, annak a bizonyos emlegetett gyaláni ároknak a szomszédságában, szintén helymeghatározással indítva:

Szérű van a házam, szérü lakom én, Gyere be galambom, magam vagyok én. Rödülöm a hajamat, várom a galambomat, Várom igazán, húzd rá te kutya cigány.

\section{Lakodalomban énekelt dalok}

Csakhogy a húzd rá cigány felszólítás már sejteti, hogy a népdal, valamint a magyar nóta egyaránt dalra fakasztotta az embereket ez idő tájt, attól függően, hogy melyik vonatkozott rá jobban. Itt jelen esetben a család ragadvány neve is, Szésőék volt, megkülönböztetendő a többi Széles családtól. Tehát a név kötelez. Lakodalmak alkalmával, amikor a muzsikusok körbe jártak a koszorús pohárral ${ }^{21}$, szinte minden alkalommal ezt húzatta Széles József. Pluszként derültségre okot adva, a rödülöm ${ }^{22}$ a hajamat rigmusnál, kopasz fejére mutatott.

Hasonló helymeghatározással indul a következő népdal is, amire úgy kérdeztem rá: a Dombi Gabi (Nagy Gábor) bácsi mit húzatott? Ezt a választ kaptam, egy pillanaton belül:

Dombon van az özvegyasszony háza,

Benne van a lánya vetett ágya.

Selyem az ágy, csipke dunyha, takaró,

Ez a kislány, de kedvemre való.

Ugyanis Nagy Gábor dombon lakott, igaz ez már a szomszéd Büssü községhez tartozik, de a négy falu lakosai (Kisgyalán, Gölle, Fonó, Büssü) még a közelmúltban is ismerték egymást. Véletlenül ráéreztem, hogy ilyetén választ fogok kapni, ráadásul népdalt! $A$ dombon van a hangsúly a szövegben ez a párhuzam, az özvegyasszony csak úgymond ráadás azzal, hogy szintén dombon él. Hasonló lejegyzett variáció, a középső sorok kis eltérésével:

Benne van a két eladó lánya,

Benne van a selyem ágytakaró.

„A vacsorakor, mindjárt a leves után, elkezdték a húzatást, mert nem lett volna vége. A muzsikásoké lett a pénz, nem is ám a gazdáé! A koszorús pohárból mindenkit megkínáltak." ${ }^{23}$ Saját emlékeim szerint 2007 ben jártak körbe utoljára lakodalmi vacsora asztalnál a zenészek.

Népdalok közül ez is elhangzott gyakorta, amelyet nagynéném, elmondása szerint: „az Eta anyjától tanultam," akit Tolna megyébe füzték rokoni szálak:

Villás farkú fecske, bátai menyecske,

hogy tudtál te ide vándorolni, az idegen földre.

Nem jöttem én gyalog, a gőzkocsi hozott,

Csalfa volt a kisangyalom szeme, azzal csalogatott ide.

\footnotetext{
21 Koszorús pohár: rozmaring szállal körbe ölelt pohár, egy tálcán, amelyböl inni kellett, a tálcára pedig a pénzt tenni.

22 Hajat göndörré tesz sütővassal.

23 Bóna Lászlóné szíves közlése.
}

A „Bátai” Sárköz Néptánc Együttes dalszövegében ez így hangzott: Nem jöttem én gyalog, mert a vonat hozott. A kisgyaláni szövegben gőzkocsi szerepel. Horváth Mária aki „hozta” ezt népdalt uzdi lány volt, férje 1905-ben született. Talán innen a mi archaikusabb változatunk.

Azt, hogy ki mit fog húzatni a lakodalom vacsoráján a legnagyobb valószínúség szerint, azt minden jelenlévő sejtette. Nagynéném visszaemlékezése szerint, Ő ugyanazt a magyar nótát húzatta legtöbbször. „Volt, amikor volt egy kis kiesés, de ez volt a fö fundamentum." - mondta. „Rámás csizmát ${ }^{24}$ visel a babám, Szeret is engem igazán." De minjárt hozzáfüzte, „volt is rámás csizmája a Lászlómnak".

Bóna János lakodalmának visszaidézése során, Pintér Gyula az 1960-as évek közepe táján a következőt húzatta:

Molnárlegény koromban,

Ott őrlettem a göllei malomban.

Míg a paraszt a lováról leveszi a hámot,

Én addig a menyecskéből kiveszem a vámot.

Pintér Gyula fonói lakos, ugyanis molnár volt Fonóban, innen a magyar nóta szövege. A mai digitalizált közösségi média előtti időkben az emberek ugyanúgy szerettek magukról információkat megosztani másokkal, akár a foglalkozásukat illetően is. „Ezért a nótáért, zöld hasú tízest kaptak a muzsikusok. Fonóban a piarista lapban volt a malom. A Fonai Gy. háza ebböl a malomból épült." ${ }^{25}$ Érdekes, hogy a nagynéném mégis a „göllei malomba” változattal énekelte.

Szabó Géza lakodalmában az 1980 - as években Bóna László az alábbi magyar nótát húzatta:

Befogom a lovamat zöldre festett kiskocsimba,

Elviszem a búzámat a göllei gőzmalomba.

Megkérem a lisztes molnárt, őrölje meg a búzámat.

Ekkortájt valóban befogta Játék nevű lovát a kocsiba. Bár az 1980-as években a munkavégzés terén már a traktoroké volt a főszerep, így Játék főként a helyi ifjúság örömére szolgált, miután felkapaszkodtunk a kocsira. Ami pedig a gőzmalmot illeti, azt a szöveghüség követelte meg, az eredeti szövegben is gőzmalom van. Göllében azonban valamikor vízimalom volt. Ez egy hasonló gesztus a gyalániak részéről, cserébe a hadihajóért.

Volt aki az utcán húzatta ezt a népies müdallamot:

Esik eső, csak úgy szakad,

Szeretnélek, de nem szabad.

Mert az Anyám nem engedi,

Nem hagyja Csórót szeretni

Az „Anyám” helyett, nem egyszer a feleség neve hangzott el. A feleség előtt, ha ezt a nótát másnak húzatta a férj, az elhangzásakor a falu egész közössége tudta, kinek is szól tulajdonképpen a nóta, „Mert akinek bánata van, könnyes szemmel ébred, ..." magyar nóta esetén is.

24 A béléstalppal való találkozásnál a felsőbőr szélére egy keskeny bőrcsíkot varrtak, ez volt a ráma, és ehhez szögezték a járótalpat. 25 Bóna Lászlóné szíves közlése 
Az esküvő előtt Kisgyalánban is szokásos volt a szerenádadás. „Lefeküdtünk egyszer csak muzsikáltak. Lukadér Lajos bácsinak volt egy harmonikája. Akkor, ha a gyertya meg lett gyújtva azt jelentette, hogy a lány elfogadta a szerenádot! Volt lány, aki több szerenádot is kapott."26

Kérdés tőlem: Gyufa!? Hát nem inkább gyertyát gyújtottatok? Válasz: „Gyertya nem volt, kutyafüle. Az a szegénység, ami volt, arról nem jó beszélni. Még az a gazdag is szegény volt." - értve ez alatt a tehetősebb falubelit. Az évszám pedig a visszaemlékezés szerint 1947.

A kinéztél az ablakon? - kérdésre a válasz: „Nem volt olyan ablak!” Itt már építészet történeti szempontok vetődnek fel, egy részt a tömésfal vastagságából adódóan azon az ablakon kihajolni sem igen lehetett, másrészt nagyon kicsi volt az az ablak. Nagynéném tekintetén látszott is, hogy minek ezt kérdezni, hogyhogy nem logikus ez számomra. „Mikor még, Te is érted ${ }^{27}$ azt a házat."

Az ekkor elhangzott magyar nóta:

Jaj de szépen muzsikálnak,

Ablakánál egy kislánynak.

Kék a szeme, gesztenye a haja,

Jaj de csínos kislány maga.

„A bálokon pedig a göllei gyerekek muzsikáltak.”28 „Bálok voltak, megszólalt a muzsika, első táncos voltam. Itt is küldtük a nótát, szív küldi szívnek, Lajos küldi Böncinek: Nem adlak másnak, ..." 29

A lakodalmak délutánján a karikázás is szokásos volt az 1980-as évekig. Hujjogatással, rikogatással tarkítva. Vidám nótákkal:

Piros, piros, piros, 3-szor is piros,

Tilos, tilos, tilos, nagypénteken bort inni.

Elszakadt a tutyimnak a kötője,

Legény legyen, aki aztat megkösse.

Lám az enyém megkötötte egy barna,

Homlokára göndörödik a haja.

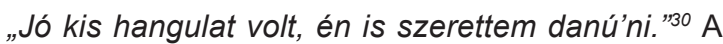
tréfásabb kedvű vőlegények, újdonsült férjek általában ezt a magyar nótát húzatták:

Nékem olyan asszony kell,

$\mathrm{Ha}$ beteg is keljen fel,

Főzze meg a vacsorát,

Úgy várja, úgy várja haza az urát.

A hasonló kedélyű menyasszonyok pedig ezt a magyar nótát húzatták:

Asszony vagyok, az akarok lenni,

Nekem ebből nem parancsol senki.

Sem Apám, sem Anyám,

Ezt szeretem igazán.

Az érzelmesebb lelkületű menyasszonyok pedig

26 Bóna Lászlóné szíves közlése.

27 Érted jelentése: éltél már akkor

28 Bóna Lászlóné szíves közlése.

29 Csima Lajosné szíves közlése.

30 Csima Lajosné szíves közlése. ezt a magyar nótát kérték a zenészektől:

Ahogy én szeretlek nem szeret úgy senki, Ahogy én csókollak nem csókol úgy senki. Így sohasem vártak, így sohase kértek, Így még nem szerettek soha, soha téged.

Minden virág az én szerelmemből nyílik, S ez az én szerelmem elkísér a sírig. Minden nóta az én bánatomat zengi, Ahogy én szeretlek nem szeret úgy senki.

Jön is erre mindjárt a vőlegény válasza:

Ünnep van nálunk, mikor eljössz hozzánk, Ami földi jó van, mindent eléd hoznánk. Jó anyám is én is szeretettel várunk, Nagy ünnep ez nekünk, mikor itt vagy nálunk.

Nagy ünnep van nálunk, de még nagyobb volna, Ha eljönnél velem egyszer a templomba. Hogyha itt maradnál örökre minálunk, Boldogság tanyája lenne kicsi házunk.

Csima Lajos válasza volt menyasszonyának, Vörös Erzsébetnek az előző magyar nótára. Násznagy húzatta magyar nóta a koszorús pohárba:

Repülj, repülj hétpettyes katicabogárka,

Mond meg néki, hogy én őt igazán szeretem,

A hófehér nyakát csókold meg helyettem.

Bank László nótája volt.

Dumik Melinda lakodalmában 2000-ben húzatták ezt a magyar nótát:

Debrecenben voltam, Nagyerdőben jártam, ...

Ugyanebben a lakodalomban került húzatásra a magánál 20 évvel fiatalabb feleséget választó göllei férj részéről ez a népdal:

Kukorica csalamádé,

Öregember vagyok már én.

Fiatal a feleségem,

Abban van a reménységem.

Kéthelyen (Marcali járás) 1957-ben özv. Mika Istvánné 94 évesen közölte ugyanezt a népdalt. Gyűjtötte Molnár Julianna. Az 1863-ban született adatközlő is azt hangsúlyozta ki, hogy hol és mikor énekelték: a lakodalomkor ünnepélyes öltözetben, a mulatók kört alakítanak és így énekelgetnek. ${ }^{31}$

Tréfás rigmusok, vicces köszöntések, is elhangzottak a lakodalom közben is:

"Fogadjunk fel egy pint borban, gyerek van a mennyasszonyban."

"Kés, tányér villa zörögnek, körülöttem a menyecskék görögnek." 32

„Rövid az élet, hosszi a sír, csináljon mindenki együtt, amit bír."

31 https://en.mandadb.hu/common/file-servlet/document/661070/ default/doc url/NA258.pdf Letöltés ideje:2020.03.03.

32 Állatenyésztési szakszó népies változata, amely a sertések termékenyülési képességére vonatkozik.

33 Bona Lászlóné szíves közlése. 
„Mi van a lukas kalács közepén? Hát a boros üveg!" - dobá'ták, csak úgy gurgutak, olyan jót derü'tünk ${ }^{34}$.

„Táncszók, ezek az országosan, föleg Erdélyben elterjedt hujjogatások, csujogatások többféle funkciót töltöttek be: gyakran táncra inspiráltak, magát a táncost bíztatták, esetleg a másik férfi táncost serkentették, vagy éppen a leány-partnert dicsérték, máskor gúnyolták. Legföbb célja volt ezeknek a szóknak a közönség szórakoztatása, mulattatása. Az emelkedett hangulatban senki sem botránkozott meg a sikamlós strófák hallatán. Rövid sorokból, esetleg néhány strófából állanak a táncszók, amelyek többségét táncolás közben mondták, de a táncok szünetében, a pihenés szakaszában is szerepet kaptak." 35

Együd Árpád által gyűjtött táncszók. „Cukorborsó szára fölfutott a fára, $A$ vőlegény létrán m’égy föl a menyasszonyi ágyra. A kis kakasnak elnémult a hangja, Mert a menyasszonynak illétben a marka. Happ, a mester, hap-hap-hap, Akkor koppint, mikor kap. Uccu banya, ugorj ëggyet, Ne sajnáld a cipellödet. Dugasz kell a hordónak, Meg az anyja lányának. A menyaszszony jaj, de szép, A két lába ájjon szét." 36

Szintén lakodalmakban a nemek közti évődéskor hangzottak el a következő népdalok Kisgyalánban:

Elhagyott a feleségem szalmaözvegy lettem,

Jézus, Mária oltalmára két szál gyertyát vettem.

Hogyha elég, ismét veszek, hogy még tovább égjen,

Hogy a kedves feleségem vissza sose térjen.

A dal második sorára talált variáció így hangzik:

A kis Jézus oltárára két szál gyertyát tettem.

Érdekes a két változatban a hasonló hangzású szavak előfordulása ugyanazon a helyen, ezek az „oltalmára” és az „oltárára” kifejezések, miközben a mondat vége ugyanaz. A dal szövege aztán így folytatódik:

Hogyha egyszer visszajönne, jaj, de megbecsülném,

Kezét-lábát összekötném, a füstre feltenném.

Hogyha szépen rimánkodna, onnan is levenném,

Befüteném a kemencét oda is betenném.

„Csak ujjan régi hagyomány, bent van az agyamba. Ahhoz tartozik ahol, a kapom a segélyt." Nagynéném optimistán, mindkét nem esetén a vissza sose térjen, és a haza ne segé'd, tréfás voltára gondolt, amikor már nem a háborús évek alatt énekelték, hanem békeidőben, lakodalomban.

\section{Katonadalok}

Az első világháborúban mind a katonákat, mind az otthon maradt hozzátartozókat élénken foglalkoztatta a hadisegély kérdése, dalunknak is ez a témája: „Húzd mëg, cigány, kapom a segélt, / Isten, az uramat haza në segéld...", 37

34 Csima Lajosné szíves közlése.

35 Együd Á. 1975: 397

36 Együd Á. 1975: 362

$37 \mathrm{https}: / /$ kaposvarmost.hu/videok/kaposvar-most/2014/12/08/ megujult-a-rosseb-bakak-emlekmuve-a-szinhaz-elott_14659. htmlLetöltés ideje:2020.02.04
Nekem sem a tréfa jutott hirtelen eszembe, hanem az a kérdés ki volt képes ilyent énekelni? A következő helyben elhangzott humoros katonadal változat már barátságosabban hangzik:

106 éves barna kislány,

Kinek foga sincs már,

Sétál a regruták után.

Hová merre, barna kislány?

Miért kérdi a kapitány Úr,

Megyek a szeretőm után.

Vikár Béla 1906-ban megjelent művében 'A pápai utczán' cím alatt a következő szöveg olvasható:

Söprik a pápai utczát,

Masíroznak a katonák.

Tizenhat esztendős barna kislány,

Megyen a regement után.

Kérdi tőle a kapitány,

Hová, hová, barna kislány?

Ne kérdje azt, ej-huj, a kapitány,

Megyek a szeretőm után.

Katonadalok több alkalommal elhangzottak a lakodalmakban is, például Mosdóson ez az I. világháborús népdal az 1980-as években:

Ha felmegyek a Doberdói Nagyhegyre

Föltekintek a csillagos nagy égre.

Csillagos ég merre van a magyar hazám, Merre sirat az édesanyám.

A harctérre szó helyett minden esetben, a "Nagyhegyre" helymeghatározás hangzott el Kisgyalánban, aminek az a magyarázata, hogy „Doberdó magas hegyen, fennsíkon terül el. "38 Ez bizony mély nyomot hagyott a magyar lélekben, ha száz év múltán is rögtön pontos helyszínrajzot ad a dalt felidéző személy. A II. világháború megpróbáltatásai legalább ennyi fájó emléket hagytak sok család életében.

Doberdó és a Don-kanyar olyan erővel vésődött be az emlékezetbe - kevés család volt, aki ne lett volna érintett - ezért ezek a nóták manapság is „szívfájdalommal, bánattal kerülnek eldalolásra. „Kint harcolt a Donnál ... - engem nagyon érint, szívszorító." ${ }^{39}$ mondja Csima Lajosné, akinek az édesapja a Donnál hadifogságban halt meg, így kislányként testvérével együtt ezt a dalt tanították meg nekik, és a falu lakossága gyakran kérte tőlük, hogy énekeljék el. A magyar nóta egészét most lejegyezte: „mert így kerek, nem szabad kiragadni belöle részleteket"

Tábortüzek lángja, világít az égen,

Halvány zöldes színű tábori levélben,

Megremeg a kezem, ha írom e pár sort, míg

Drága feleségem írjál, ha megkapod kedves.

Mi újság van otthon, vártok e még vissza,

Szomorú könnyemet e lapom felissza.

Most egy gránát robbant, majdnem ide vágott,

Érzi e a szíved, veszélyben a párod.

38 Bóna Lászlóné szíves közlése.

39 Csima Lajosné szíves közlése. 
Hát a kicsi fiunk meg nőtt e már szépen,

Tud e már beszélni, írd meg azt levélben.

Tudja e mondani drága jó apukám,

Ugye a harc után visszajössz majd hozzánk.

Tedd össze kacsóját, ha eljön az este,

Tanítsd imádkozni, s hazaszeretetre.

Csókollak ezerszer, kis fiamat százszor,

Tábori levelem én ezzel bezárom.

Tábortüzek esti fénye világít az éjbe,

Halovány zöld színű tábori levélre.

Megremeg a kezem, míg írom e lapot,

Édes kicsi asszony írjál, ha megkapod!

Mi újság van otthon, vártok-e még vissza?

Szerelmes könnyemet ez a levél issza.

Most egy gránát robbant, majdnem ide vágott,

Érzi-e a szíved, veszélyben a párod?

Hát a kis fiacskánk megnőtt-e már szépre,

Tud-e már beszélni? Írd meg a levélbe!

Tudja-e mondani: drága jó apukám

Ugye a harctéren vigyázol most reám?

Tedd össze kacsóját, ha leszáll az este,

Tanítsd imádkozni, hazaszeretetre.

Csókold meg helyettem, ha eljön az álma,

Ő a mi szerelmünk nyíló szép virága!

Írom a levelem, riadó van éppen!

Hogy ez után mi lesz, nem tudom én sem.

Csókollak tégedet, fiamat is százszor,

Tábori levelem én ezzel bezárom!

Magyar nótáról lévén szó szövegváltozatról nem beszélhetünk. Írott formában még levélként is haza küldték a katonák. Így tett Dr. Bárkovicz Ferencz is Balassáról, aki folyóírással vetette papírra, így nem derült ki a középiskolás lelkes forrásközlőnek, hogy tulajdonképpen magyar nótáról van szó: „Meglepődtem a levél stílusán, a nők iránti tiszteletén. Az az udvariasság és előzékenység, amely abban az időben minden férfiban megvolt, az a mai fiúkból lassan teljesen kihal (...) annak idején sajnos lemaradt a levél aljáról a dátum. ${ }^{40}$ te le:

A következő katonadalokat Csima Lajosné jegyez-

Házunk előtt mennek a katonák,

Jaj de szépen fújják a trombitát.

Elöl a hadnagy, aki vezet,

Gyere rózsám fogjál velem kezet.

Nem fogok én hadnagy úrral kezet, Inkább várok szerelmeslevelet.

Máma megírom, holnap elolvasom,

Holnapután el kell masíroznom.
Ez a vonat most van indulóban,

Az eleje fel van virágozva.

Az eleje sárgára, bevonuló öreg bakák számára, Jönnek haza végleges szabadságra.

Be van az én zubbonyzsebem varrva,

Barna kislány mit keresel abban?

Benne van a zsoldkönyvem,

Meg a leszerelö kiskönyvem,

Már ezután barna kislány a kedvesem.

„Magyar katonadal a II. világháború idejéből, de utána is dalolták, és ma is dalolják. (...) A magyar népdal éneklésének, s ezen belül a magyar katonadalok éneklésének a vonzalma történelmi változásokra való tekintet nélkül sohasem szünt meg. A nép - benne a nép katonája - gondolatait, érzelmeit, örömét és bánatát dalban tudja ma is szebben, jobban és megkapóbban kifejezésre juttatni. A magyar dalkultúra e tekintetben igen gazdag, ami a magyar folklórtermés kimeríthetetlen forrásából fakad. (...) Egy részük dicsőséges, bátor katonaéletröl, a haza hüséges - minden nehézséget és önfeláldozást is vállaló - szolgálatáról szól, a másik részük pedig a keserves, a megpróbáltatásokkal járó nehéz katonaévek, a magyar történelem viharainak szomorú napjairól maradtak fenn. Ezek a katonadalok a magyar katona élete, vitézsége, hazaszeretete, érzelmi és szellemi világa, az otthonért, a kedvesért, a hazáért való aggódásának hü bizonyítékai." ${ }^{11}$ A katonadalok közül kedvelt volt még ez a gyakran énekelt magyar nóta Csima Lajosné jegyezte le:

Dunántúli nádfedeles kisház,

Ablakában sírdogál egy kislány.

Ne sírj kislány, lesz is, jobb is,

Majd, ha egyszer viszont látjuk egymást.

Csak még egyszer tudnák haza menni,

Végre haza segített az Isten.

Olyan kihalt, olyan árva minden,

Az hagyott el, akit úgy imádtam.

Aki után mindig haza vágytam,

Jobb lett volna messze idegenbe ...

Bóna Lászlóné énekelte katonadalok:

El kell mennem katonának,

Jaj, Istenem, jaj, de nagyon messzire.

Itt kell hagynom a babámat,

Azt sem tudom, hogy kire.

Rád hagyom édesanyám,

Vigyázzon a göndörhajú babámra.

Járjanak el a templomba imádkozni,

Minden áldott vasárnap.

Százados Úr, levelem jött,

Hogy a babám nagyon beteg utánam.

Kaphatnák-e szabadságot,

Hogy még egyszer megláthassam.

40 http://www.csukas.sulinet.hu/csukasmagazin/csukasmagazin\%202012-II-evf-01.pdf Letöltés ideje:2020.03.04

41 Jósa I. 2003: 56. 166. 
Jól tudom, ha engem meglát,

Egyszerüen meggyógyul a bajából.

Az ellenség, meg sem tudja,

Hogy egy baka hiányzott a csatából.

Kikötöm a lovamat a kaszárnya elejbe, Hullajtom a könnyem a hacacáré kötényembe. Lehajtom a fejem a barna babám ölébe,

Ez a kislány kiment az erdőszélére.

Szedi az ibolyát, föltekint a magos égre,

Szedi az ibolyát, föltekint a magos égre,

Haj Istenem a szeretőm viszik a Szerb határszélre.

Érdekes tapasztalat, hogy a helyi variációknál, midig pontosabb helymeghatározással találkozunk, mint az egyéb változatoknál, ott ugyanis inkább a harctér kifejezés szerepel több katonadalban. ${ }^{42}$ Erre látunk itt egy példát:

Szedi az ibolyát, sürün fel tekint az égre,

Jaj, Istenem a szeretőm most viszik a harctérre.

Király Lajos írja somogyi katonadal gyűjtéséről: „Adatközlőink fele nő volt, ők is jól tudták a katonanótákat. A lányok és asszonyok dalainak egy része természetesen külön csoportot alkot: ezeket nem énekelték a kaszárnyában vagy a fronton, sajátosan az itthon maradottak érzelmeit fejezik ki. A katonadalok értékes kortörténeti dokumentumokat jelentenek. Az elmúlt idők katonai kiképzési módszereiröl hiteles, érzelmi töltésü leírásokat nyújtanak"43

Az itt következő I. világháborús magyar nótát, az iskolában újonnan érkező kislánytól (akinek szülei gazdasági cselédként dolgoztak az uradalomba) tanulták a kisgyaláni gyerekek az 1930-as évek második felében:

Volt egyszer egy hadnagyocska,

Fiatal volt és bohó.

Büszke volt a szíve-lelke,

S minden szépröl álmodott ...

\section{Summásdalok}

A kisgyaláni gyerekek nem jártak együtt iskolába a summás gyerekekkel, mert ők szezonálisan dolgoztak, de dalokat tölük is tanultak, és a kíváncsiság is odavezette a helybélieket hozzájuk.

„A zalai summás lányok is énekelték, karikáztak vasárnap délután, elmentünk mi falusi lányok megnézni őket a barakba ${ }^{44}$, hamarosan begyüttek az oroszok ezután. Karikázás közben énekelték:45

Három éjjel három nap, nem elég a lábamnak, húzd meg még, a lábamnak nem elég.

\footnotetext{
42 Magyarázatul számomra, Nagynéném precíz földrajz tudása szolgált.

43 http://somogy.hu/publikaciok/kiraly-l--peter-m-kaposvarivaroshazra-rasutott.html Letöltés ideje: 2020.01.03.

44 Summások számára készített, szálláshely.

45 Bóna Lászlóné szíves közlése.
}

A hármasság népköltésünk képnyelve szerint a teljesség, a tökéletesség, a befejezettség képe. Szintúgy kell érteni a hármas számot, mikor azt mondja a népköltés: „Három a táncz mindhalálig, Kivilágos kivirradtig." Ez azt jelenti, hogy akkor teljes, igazi, tökéletes, mikor három. ${ }^{46}$

\section{Béresdalok, szolgadalok}

„Esténként danú'tak, az aratók, kapások, nem hagyták el magukat. Hottó papa volt a gazda." ${ }^{\text {"47 }}$ Az aratódalok közül felelevenítésre került népdal:

Nem pihentem jaj, de sokat arattam a nyáron.

Jaj, de sokat arattam a nyáron,

Nem pihentem ki magam az ágyon,

Vesd meg babám ágyadat, selyem ágyadat,

Hagy pihenjem ki rajta magamat.

„A panaszos hang sok müfajcsoporton belül felcsendül. Ezzel a hangulattal találkozunk a keservesek, bujdosóénekek, rabnóták, vándordalok, valamint a szolgaés a béresdalok esetében is. (...) Nem ritka eset, hogy ezek a dalok visszanyúlnak régi dalok szövegeihez és dallamaihoz, de találunk olyanokat is, amelyek e dalok mintájára készült müköltési alkotások. Somogyban különösen a századforduló után terjedtek el rohamosabban és az itteni emberek kedvelt dalaivá váltak. Találunk közöttük olyanokat, amelyekben régebbi dalaink szövegei aktualizálódnak, közöttük legszebbek azok, amelyek az aratásról, az aratópárokról szólnak." ${ }^{8}$

A summás lányok által dalolt magyar nóta a következő:

Elkerülsz, mert szegény vagyok,

Nem kell néked olyan kislány, kik dolgozni járnak,

Nem kell néked olyan kislány, kit gyötör a munka,

Mert azt hiszed, mivel kezem a lelkem is durva.

Mert azt hiszed kis kunyhóba, nem tudsz boldog lenni,

Mert azt hiszed, aki szegény, nem is tud szeretni.

Hej pedig a nagy Úristen nem teremtett rangot,

Szívet nemcsak gazdagoknak, a szegénynek is adott.

Mert a szegény nem szabad, csak a lelke gazdag.

\section{Iskolában tanult dalok, százéves magyar nóta}

A dalokat nem írták le, hallás után könnyen megtanulták, legyen az munka, tanulás vagy szórakozás közben. Pintér tanító úr 1937-ben a „rétbe” elvitte kirándulni a gyerekeket. (Akkor egy tanítóra 59 gyerek jutott). „Amikor a kövesutat csinálták, a gölleiek nem akarták a fö' djeikre engedni az utat, ami érthető dolog, féltették a földjeiket. Elmentünk megnézni a kütörőt. A tanító úr énekeltette a nótákat a Csima Sanyival (szül.: 1928), aki már nagyobbacska gyerek volt, Csima sógor, a Sa-

\footnotetext{
46 https://mek.oszk.hu/06600/06664/html/01.htm A magyar népköltés remekei I. Letöltés ideje: 2020.01 .03

47 Csima Lajosné, anyai nagyapja Hottó

48 Együd Á. 1975: 392
} 
nyi apja a katonaság alatt tisztiszolga volt, tőle tanulta a nótákat. A tanító is kíváncsi volt, a mi agyunk meg bevette. Három nóta hangzott el ekkor."49

A pozsonyi sétatéren magyar lányok, fiúk járnak kelnek,

Nagy Petőfi szobra mellett virágot hinteni is lopva mernek.

A pozsonyi sétatéren szól a zene, cigányzene,

Rákiállt az egyik Cseszi ${ }^{50}$ ide cigány a fülembe, Húzz nékem egy oláh nótát szaporán, de cifrát.

Nem tehetem, Nagyságos Úr, csak az Isten tehet róla,

Nem jön más ki a hegedűmből csak a magyar nóta.

„Petőfi szobrát a pozsonyi sétatéren 1921-ben bedeszkázták, majd a Grassalkovich palota egyik istállójában helyezték el. A szobrot a 20. század ötvenes éveiben a Duna túloldalán, a Sad Janka Krála parkban (Városi díszliget) állították fel újra. 2003-as restaurálását követően a Petöfi-szobrot a pozsonyi Medikus-kertbe helyezték át." ${ }^{51}$ A dal felelevenítése 2020-ban történt, a 100 éves évfordulókor énekelte el nagynéném. Trianon kapcsán, az események ismeretében tudjuk, hogy 1921-ben már nem vihettek virágot Petőfi szobrához. Ezt a magyar nótát, amelyben négy nemzet: a magyar, a roma, a román és a cseh is szerepel, nem találtam meg az interneten. Míg a többit, legyen az népdal, magyar nóta, valamely variációját megleltem. Mivel 1921ben már nem vihettek a pozsonyi Petőfi szoborhoz virágot, így ezzel aktualitását vesztette ez a magyar nóta.

Könnyen belátható, hogy Trianon emléke már réges-rég nem az elsődleges tapasztalatból táplálkozik és nem is kommunikatív emlékezetünk része. Trianonra személyesen nem emlékszik már szinte senki. (...) Amit ma Trianonról tudunk, az a kulturális emlékezet része." 52 Bizony a tények ismeretében, itt még az „elsődleges tapasztalatból táplálkozott” az előadó.

„El ne vesszen, okvetlenül le kell írni!” - mondta nagynéném, miután eldalolta. Biztosítottam afelől, hogy ezeket a dalokat lejegyezték, azonban úgy tűnik ráérzett, hogy valójában már kevesen ismerhetik, vagy tényleg azok közé tartozik, amelyek talán elvesztek azóta, ahogy erre Fekete István is utalt a régi magyar nótákkal kapcsolatban.

Csima Sándor akkor a réten ezt is énekelte:

A pécskai cigánysoron nagy a sírás, rívás,

A pécskai cigánysoron haldoklik a prímás.

Ezüst botján támaszkodva kesereg a vajda,

Nem látszik a nagy tisztesség, csak a bánat rajta.

Kálmán fiam, hívjunk papot, mi a kívánságod?

Mielőtt az Atyavajda trónusát meglátod.

Nem kell a pap, minek a pap, csak az a kérésem:

A hegedüm, a hegedüm temessék el vélem.

49 Bóna Lászlóné szíves közlése.

50 Csehszlovák szóból rövidítve.

51 https://www.kozterkep.hu/29615/Petofi_Sandor_szobra Pozsony 1911.html Letöltés ideje :2020.01.03.

52 (PDF) Trianon traumatikus emlékezetéröl | Eva Kovacs ...ww. academia.edu > Trianon_traumatikus_emlékezetérö Letöltés ideje :2020.01.03.
Megbocsájtja a nagy Isten, tudom minden bünöm, Ha a kedves nótáját majd el-elhegedülöm.

Hátra fordul s lopva, titkon könnyet ejt a vajda, Kálmán cigány az Istennek hegedül már nagyba.

A harmadik, ekkor elénekelt magyar nóta utolsónak került közlésre.

A kivándorlás is élénken foglalkoztatta az itthon maradottak gondolatvilágát, érzelmeiket dalok formájában adták elő:

Tavasz végén kinyílik az akácfa fehér fürtös virága,

Alatta egy barna legény most indul a nagyvilági útjára.

Föl-föl sóhajt, búcsúzkodik, Isten veled falu legszebb leánya,

Visszajövök, mire lehull az akácfa fehér fürtös virága.

Ötvenszer is lehullott az akácfa fehér fürtös virága,

Alatta egy öregember most jött meg a nagyvilági útjából.

Föl-föl sóhajt, múltra gondol, vénasszony lett a falu legszebb lányából,

Visszajöttem mire lehull az akácfa fehér fürtös virága. ${ }^{53}$

Ennek a magyar nótának is megvolt az érzelmi alapja, a legény kivándorolt az éneklő leány itthon maradt. Még az ebben az évtizedben bekövetkező 1929-1933-as gazdasági világválság esztendeit minden szónál szemléletesebben érzékelteti az alábbi Parasztkesergő. ${ }^{54}$

Volt két ökröm, két szép villás szarvú,

Címeres két ökröm, fehér, mint a hattyú.

Csellő, Csákó, Bimbó az ekét tartottam,

Dalolt a pacsirta, amikor szántottam.

Egyszer csak azt mondják, ki ad többet érte.

Ökrömet a törvény elkótyavetyélte, elkótyavetyélte.

Volt nékem földem is, búzát termö földem,

Ringó kalásziba el-elgyönyörködtem.

Szalad, szalad, szalad, az idő elszaladt,

Hívta, hívogatta az adó, a kamat.

Nincs már nékem földem, nem maradt egy rög sem,

A pár hold örökségem elszaladt örökre.

Nincs már nékem földem, csak az anyám sírja,

Szegény ember sorsát, boldog Isten bírja.

Volt nékem házam, kicsiny fehér házam,

Muskátli virított a két ablakába.

Hajléktalan lettem pergő dob szavára.

Másnak nyílik már a muskátli virága.

Tornyunk kis harangja bánatosan sírja. ${ }^{55}$

Tulajdonképpen ez a parasztkesergő, a szociális panaszdalok közé tartozó magyar nóta, amit még 2007-ben nem tudtam, akkor Gyarmati Józsefné versként szavalta el.

\footnotetext{
53 Bóna Lászlóné szíves közlése.

54 Gyarmati Józsefné (Hartmann Mária 1924) Büssübe ment férjhez. Kisgyalánban töltötte gyermekkorát, a Györfi, Babócsai családok leszármazottja, szíves előadásakor jegyeztem le a Parasztkesergőt. 55 Lanszkiné Széles G: 2007: 62.
} 
„A gazdák első világháború elötti tömeges tönkremenetelének ad hangot Pósa Lajos - Dankó Pista 'Volt nekem, volt nekem búzatermő földem ...' kezdő sorú, Szegény ember dolgát ... címen emlegetett népies müdala, mely - igen jellemzően - A magyar nép kesergője c. kottafüzetben jelent meg először. E dalhoz minden bizonnyal felhasználtak hasonló előképeket, népünk pedig átvette és tovább alakitotta úgy, hogy a folklórizált változatokból nem is lehetett már az eredetire visszakövetkeztetni." ${ }^{16}$ Minden esetre az első világháború előtt is, és a gazdasági világválság esztendeiben egyaránt időszerű volt.

„A II. világháborút követően a háborúban meghalt, vagy hadifogságba került férfiak hiánya következtében az asszonyok is kénytelen voltak férfimunkát végezni. Még a vén Ménküs is kaszált! Az aratás férfierőt igénylő munkájába - a kaszálásba - a nőket is bevonták, míg a marokszedés természetesen női munka volt. A kor akkori nyomdafestéket nem tűrő, de igen jól rímelő kis rigmusa a követekző:

Vajon kié ez a nyárfás?

Tiéd meg az enyém elvtárs.

Ha visszajön a gazdája,

Mehetünk a bús ...

Kérdően néztem Bóna Lászlóra, sógoromra, hogy ezt akkor, hogy írjam le?! Kis gondolkodás után azt válaszolta: „Írd azt, hogy a másvilágra!” - úgyis is rímel.”

Nem hiába mondják ránk nagy általánosságban, hogy somogyi bicskások. Öt esetet sikerült megtudnom, de biztosan van ezen felül is több példa saját falumban, amikor kinyílt a bicska. Ezek közül a legemlékezetesebbek a következők. Így történt az 1920-as évek végén Szipliék kocsmájában is, melyből haláleset nem származott. Nem úgy, mikor is Major Péter lett az eset kárvallottja, amit még a szakcsi hírversíró is megénekelt:

Tudjátok-e Kisgyalánban mi történt?

Azt a híres Major Pétert megölték.

Fehér nyelü kést szúrtak a szívébe,

Ott feküdt ki a csárda közepiben.

Ez az eset Weisz bácsi kocsmájában történt. A lámpát leverték, így igazából nem volt világos, hogy ki tette. Több jelenlévő is a gyanúsítottak listájára került. A csendőrök nem hagyták kihülni az ügyet, több kihallgatás volt. Ezeknek az lett a következménye, hogy volt olyan, aki útilaput kötött a talpa alá és kivándorolt Amerikába. Eleinte pénzt és levelet is küldött haza. Azonban más esetek kapcsán is meg volt a betyárbecsület a falusiakban, több név is elhangzott a gyilkossággal kapcsolatban, de a csendőrökkel nem osztották meg ${ }^{57}$.

„Bizony Gölle, de általában az egész megye híres volt bicskájáról, és azt hiszem, hogy azokkal, akiket Somogyban a nyári búcsúk leszámoló borgőzében segítettek át a másvilágra negyedszázad alatt, betelne velük egy kisebb temető. A búcsúról s a cigányokról jut eszembe az egyik búcsú, ami arról volt nevezetes, hogy egy nagyon jó arcú muzsikus cigány is megjelent há-

56 Katona I. 2002: 298

57 Lanszkiné Széles G. 2007: 237. zunknál, akire talán nem is emlékeznék, ha nem akkor láttam volna először „valódi” cigányt, akinek egyetlen vastag ágba font haja a térdét verte. Ezenkivül pedig nemcsak kitünően muzsikált (ezt apám állapította meg, aki maga is hegedült), de tudta az összes akkor divatos Fráter-nótákat, sőt olyan nagyon régi magyar nótákat, amelyek talán elvesztek azóta. Amikor aztán ez a kedves muzsikus engedélyt kért, hogy egy-két nagyon öreg cigánydalt is elénekelhessen, én úgy éreztem öt-hat éves koromban, hogy a búcsú akkor lett valóban ünnep azon a ragyogó nyár végi délutánon." ${ }^{8}$

Fekete István 1905 vagy 1906 béli emlékei a szomszédos Gölléből, néhány emberöltővel később - 1975 körül - itt Kisgyalánban hasonló emlékeket ébresztettek bennem, amikor búcsúkor az udvarunkban az idős cigány muzsikus szólóban hegedült.

A koldulás is megszokott dolog volt az 1920-40-es években. A faluban különösen kedveltek egy öregedő koldus asszonyt, aki, ha megjelent mindenkiktől remélhetett egy-két merőkanál kenyérlisztet a hátán lévő bugyorba. Évente kétszer-háromszor jött a faluba. „Az emberek örvendték, vágyták az énekét, mert öneki meg nagyon szép hangja volt". - mondja nagynéném, aki 80 év múltán is emlékszik a szövegre és a dallamra:

Megnyílott a mennyországnak aranyos ajtaja,

Leszállott a földre Mária szüzanya.

Luordes városának közel, s közelében,

Ott térdepel Bernadett összetett kezekkel.

Magasan tartja kezében olvasóját,

Tiszta szívvel mondja az Üdvözlégy Máriát!

Férje a falu elején maradt szekerükkel. Az évek során így sikerült egy holdacskát összevásárolniuk. ${ }^{59}$ Egy másik somogyi variáció így hangzik:60

Megnyílt a mennyország gyönyörü kapuja,

Ott áll Szűz Mária, mint egy fényes csillag.

Fehér a ruhája, aranyos a haja,

Mária, Mária, tengernek csillaga.

Szegény árva néped sírva kiált hozzád,

Hallgasd te mëg kérésünk drága Szűz Mária!

Kérjed szent fiadat, a te Jézusodat,

$\mathrm{Ne}$ hagyj el bennünket, szegény magyarokat.

\section{Balladák}

A vallásos hangvételü dalok mellett a balladák közül az egyik legismertebb:

Bíró Ferenc Margit nevű leánya,

Akinek ma tíz faluban nincs párja.

De Margitot sok legény csalogatja,

De legjobban Kiss Imre biztogatja.

Kiss Imrének más ütött a szívébe,

Üzenetet adott fel Cserépéknek.

Hogy ők egyszer el fognak oda menni,

A bátyjával Cserép Zsuzsit megkérni.

58 Fekete I. 1976: 64

59 Lanszkiné Sz. G. 2007: 237

60 Együd Á 1975: 252. 
$\mathrm{El}$ is mentek ők oda szombat este,

De Cserépné már a kapuban leste.

Egy pár szóval, páros csókkal fogadta,

Kiss Imrének az asztalnál helyt adtak.

Éjfél után egyet ütött az óra,

Kiss Imre már elindult a nagy útra.

De Cserépné e szavakkal kísérte:

Holnap menjetek el a pap elébe.

Holnap menjetek el a pap elejbe,

Neveteket irassátok a könyvbe.

De hogyha ezt Bíró Margit megtudja,

Leányomat örökre elátkozza.

„A ballada elbeszélő költemény, amely megrázó, vagy tréfás történetet tömören, drámaian, szinte csak a szereplők szavaival ad elö. (...) Epikai, mert elbeszél, lírai, mert dal, drámai, mert párbeszédre épül. ${ }^{161} \mathrm{Az}$ 1970-es 80-as években a népballadák közül a legkedveltebbek még eléneklésre kerültek.

Bodó István (szül.: 1916) népi fafaragó Inámban született. Fonói lakosként nagyon szép hangjának köszönhetően, a tsz. kirándulások alkalmával szinte kötelezően felkérték, hogy a buszban énekelje el a 'Szendre báró leánya' címú népballadát. Nyugdíjas éveiben foglalkozott föként a faragással. A fonói templom számára készített áldozórács és a keresztelő medence ma is méltó dísze a templomnak ${ }^{62}$ „Szendre báró lánya, Bárólány ballada: újstílusú ballada. Elsö nyomait, három versszakot Magyari Költeményei (1858) között találjuk. Simonffy Kálmán 1858-ban megzenésitette. Népszerüségét jelzi, hogy a századfordulón megjelenő 'Hatszáz Nemzeti Dal' c. antológia a leghíresebb költemények között közli, és ponyva-füzetekben való terjesztése meg inkább elősegítette a szöveg egységesedését. A ballada két altípusa ismert: a) Szendre, (Szedri, Endrö, Orczi, Szirmai, stb.) báró leánya beleszeret a juhászlegénybe. A báró lánya keresésére indul; a számadó elárulja a bojtárt. A legényt felakasztják, a lány hosszasan siratja. Meglehetősen egységes szöveggel országszerte elterjedt. - b) A báró lánya, a ballada hőse beleszeret a gulyásba, a légyott miatt elcsatangolt nyájat a báró (báróné) a lánya kérésére kiváltja, de a legényt akasztófára juttatja. Más változatok szerint a kitagadott lány kedvese felesége lesz és kiegészitik a szöveget moralizáló résszel, miért nem való bárólány gulyásnénak. Változatait az előzővel kisebb számban jegyezték fel, elsősorban pásztoroktól az ország különböző vidékén. Gyakori a két altípus keveredése, a kivégzés motívuma sokszor hasonló a betyárballadákéhoz. A történet csírájában - szerencsés végkifejlettel - szerepel Apor Péter 1736-ban írt Metamorphosisában. ${ }^{63 "}$

Bodó István által énekelt a pesszimistább változat, ami a juhászlegény akasztásával végződik. A 'Gróf és az apá-

61 http://www.nagykunreformatus.hu/content_g/letoltesek/ Szabone weboldala/ballada.html Letöltés ideje: 2019.10.15.

62 Lanszkiné Széles G. 2013: 205.

63 https://regi.tankonyvtar.hu/hu/tartalom/tkt/magyar-neprajzilexikon/ch23.htmlLetöltés ideje:2019.08.12. ca' a 'Szendre báró leányához' hasonló témájú, azonban ebben a mienk, a kisgyaláni az optimistább változatú:

„Egy magas hegytetőröl, a völgybe néztem át, ott láttam három szép grófot, ki csónakon halász. A legeslegifjabb gróf, ki a csónak szélén áll, arany serlegéből kínál, hogy igyam izzó borát. Minek ez a serleg nékem, mert úgysem ihatom, mert én szegény apácalány, te gazdag gróf vagyol. Meghúzták a csengettyüt a zárda ajtaján, hova tünt el az a szép leány, és ide bejött már, $s$ ki se mehetek. Rátok gyújtom a zárdát, ha be nem eresztek, ez alatt kijött a lány talpig fehérbe, rövidre levágott hajjal, hisz fel van szentelve. Elhoztam a gyürüt, én ezt el nem fogadom, mert én apáca maradok. Ha te apáca, én elmegyek papnak, hogy a szívünk együtt maradjon."

Vargyas Lajos gyűjtéséből való a következő:

„A hegyre mentem én föl, a völgybe néztem át, ott láttam három grófot, csónakon halász. A legkisebb gróf, ki kormánypárti volt, egy szép szegény leánynak régen udvarol. De szegény volt a leány, nem lehetett övé, igy hát bevonult szegény a zárdafal közé. De rögtön ment is a gróf, mingyárt becsengetett: hol van az új apáca, ki máma érkezett? Ide be nem jött senki, de ki se mehetett! Rátok gyújtom a zárdát, ha ki nem eresztitek! Erre kilépett a lány, talpig fehérbe áll, haja rövidre vágva, hisz kész apáca már. Erre lehúzta a gróf ujjáról gyürüjét: fogadd forrón, szerelmem, szívemnek zálogát. De minek fogadjam el, hisz úgyse hordhatom: hogy ifjú gróf a férjem, azt úgyse mondhatom. De minek fogadjam el, hisz úgyse hordhatom: zárdába kell maradnom, ezt én is jól tudom. Erre kivette a gróf a töltött pisztolyát, szíven lőtte a leányt, azután önmagát."

Vargyas Lajos összesítése szerint 19 változatát ismerjük, a legelső feljegyzés is csak 1923-ból való. Valószínűnek látszik, hogy cseh-német, vagy morva vásári énekesek révén honosodott meg népköltészetünkben. Ponyvaeredete bizonyosnak látszik. ${ }^{64}$

A következő népballadai eredetű népdal gyökerei is régmúltra nyúlnak vissza, Kisgyalánban ez a versszak és változat ismert, amely két versszak ötvözéséből keletkezett:

Kocsmárosné hallja, van-e sörre, bora, söröm is van, borom is, szép eladó lányom is. Kocsmárosné hallja, van-e vetett ágya, ágyam is van, párnám, selyem belefekszem, magam is a vendégek számára.

„Legkorábbi följegyzése: 1870-1871. Dallamai igen sokfélék (Vargyas 38 félét sorol fel). Általánosan elterjedt, jellemző dallama valószínüleg szlovák eredetü, idegen járású dallam (39 változatban), a többiek csupán egy-két esetben fordulnak elö - Kocsmárosné, hálljá: Ván-é piros borá? - Söröm is ván, borom is ván, Vendégim számára! Kocsmárosné, hálljá: Száz icce bort hozná? Száz icce bort ánná?" 65

64 Vargyas, II. 621.Digitális balladatár - Amint a hegy tetejéröl Letöltés ideje:2020.03.25

65 adattar.vmmi.org > fejezetek > 09 betyardalokBETYÁRBALLADÁK (57-121.) https://regi.tankonyvtar.hu/hu/tartalom/tkt/magyar-neprajzilexikon/ch23.htmlLetöltés ideje:2019.08.12. 
Ugyanúgy ahogy a balladák eléneklése is több esetben személyhez kötött volt, úgy szintén mindenkinek megvolt továbbra is a maga nótája, amely nótáról a közösség tagjai is tudták, hogy „kié”.

Édesapám (szül.: 1929) nótája volt:

Házunk tetején, zsúpfedél van,

és ha tél van, összebújunk kicsi párom.

Huszonéves korában valóban zsúpfedél fedte a házukat. A házak előtt akkortájt még mindenhol volt kispad, így hát ez a nóta is időszerű volt, mikor énekelgette:

Kiültek a vénasszonyok a padra,

Úgy is tudom, hogy rólam szól a pletyka.

Nem kérem én a jó Istent csak arra, csak arra,

Ragassza le valamennyit a padra.

Ez a népdal is vidámságra okot adó alkalmak esetén hangzott el:

Sárgaföldes gödörbe, likat ásott az ürge.

Gyertek lányok ásóra, kapára, ürge van a határba.

Mert az ürge hun lefekszik, hun feláll,

Míg a lyukra nem talál, a sötétben.

Elment a pap ürgézni, ürgézni,

Elfelejtett fütyülni, fütyülni.

Mert az ürge a füttyszóra föl-föl áll,

Míg a likra nem talál.

Néha van azonban egy kis csalafintaság, első alkalommal néném úgy énekelte, tudta, hogy írom: „Elmentem én ürgézni, ürgézni." Mikor elmondtam, hogy én azt a variációt találtam meg, hogy a pap megy ürgézni, azontúl már ő is úgy énekelte. Csak, mint mondta nem akarta a papi hivatást belekeverni. ${ }^{66}$

Újvidéki 1951-es gyűjtésből származó ugyanezen népdal, kis különbséggel: „Elment a pap irgésznifirgészni, (ürgészni-fürkészni), elfelejtett misézni-misézni. Gyertek, lányok ásóval-kapával, ürge van a határba, határba. Ürge van a határba, határba, nincsen, aki kiássa, kiássa. Mert az ürge hun leáll, hun feláll, Míg a lukra nem talál, nem talál."

„Papcsúfoló nóta. Az egész népéletet és szokásokat belengi a vallásos szellem, az évszázadokon át tartó vallásos nevelés, a község kollektív vallásos fogadalmai sem tudták elérni, hogy az őseredeti néphumor meg ne nyilatkozzék szinte a székelyekével versenyző vaskos szellemességgel."67

„A kórházban is el kellett énekelni 2019-ben is, a vízváriaknak is elénekeltük." - emlékezett vissza nagynéném. A Kisgyaláni Petőfi Termelőszövetkezet testvér termelőszövetkezete a Vízvári Termelőszövetkezet volt. Az 1970-es években háromszor is viszont látogatták egymást tizen-egynéhány fővel az asszonyok.

A gyalániak humoros dalaiért cserébe, a vízváriak is hasonlókra tanították testvér tagtársaikat, többek közt ezekre is, népdalra, magyar nótára egyaránt:

66 A gyüjtések során, többször előfordult, hogy a szíves visszaemlékező cenzúrázza saját magát. Azonmban az is előfordul, hogy elhangzik: most már leírhatod.

67 adattar.vmmi.org > cikkek > hid_1988_10_14_czimmerDATOK KUPUSZINA NÉPRA jZAHOZ*
„Bárcsak engem valaki, valaki, hordó gyanánt fúrna ki, fúrna ki! Meg mondanám én neki, én neki, nagy a fúrú, vegye $k i$, vegye ki!"68

Ehhez hasonló a 'Három dinnye van egy száron, van egy száron, van egy száron'69, vagy a 'Három szabó legények ${ }^{70}$, és az 'Érik a ropogós cseresznye ${ }^{71}$. A vidám hangulatot fokozta, akárcsak a 'rödülöm a hajamat', kopasz ember esetén, ha valamely dolog szöges ellentétjéröl van szó a valóságban. 'Zöldre van a, zöldre van a, rácsos kapu festve ...', de aki énekelte nem volt semmilyen kerítése. Hasonló módon a lakó körülményekre is utal a többszörönként énekelt 'Putriban lakik a Sári ....

A lakás körülmények célzott javításáról, talán ebben a nagynéném által sokat énekelt népdalból lehet értesülni ${ }^{72}$ :

Arra alá dörög az ég meg-meg villámlik,

A rákói cigánygunyhó éjjel nappal ázik.

Benne van az öreg cigány, meg a kilenc rajkó,

Bever rajta záporeső, mert nincs rajta ajtó.

Ergye cigány, hozzá' deszkát, csináljunk rá ajtót, Hogy ne ázzon, dideregjen az a kilenc rajkó.

„Az ajtóban tüzeltek, gödör volt lent, valóban így éltek." Nagynéném még arra is emlékezett, hogy a férjétől tanulta. Somogy megyei gyűjtésben nem találtam meg ezt a népdalt, de Erdély és Gömör megyei gyüjtésben hasonló tartalommal igen. Ezt a cigánykeserves és cigánytáncot: ${ }^{73}$

Erdőszélen masírozik egy cigánykaraván,

Fölötte egy sárgarigó magas jegenyefán.

Rigó, rigó, sárgarigó azt fütyöli szépen,

Cigányélet a legárvább a földkerekségen.

Esik eső dörög az ég, nagyokat villámlik,

Ez a rongyos cigánysátor, kívül-belül ázik.

A következő is mintha a miénkkel ötvöződne, de még itt is vándorlásról esik szó, a mi estünkben pedig már úgymond szilárd építményről beszélünk. A dalszöveg tovább fejlődésének lehetünk tanúi, a Kisgyalánban énekelt esetben.

Kertek alatt vándorol a cigánykaraván,

Sárgarigó megszólal a magas jegenyefán.

Azt fütyüli, azt dalolja sárgarigó ágon,

68 Tízszótagos sorokból álló, ereszkedő, pentaton vázú, régi stílusú ugrós dallam. A sorvégi szinkópák kihangsúlyozzák a táncos karaktert. Ezt a dallamtípust $A$ Magyar Népzene Tára X. kötetében 19 változat képviseli, ebből 15 vajdasági adat! Elmondások szerint a kezdőstrófát vajköpülés közben énekelték. Ennek nyomán munkadal jelleget is tulajdoníthatunk a markánsan ritmikus táncdallamnak. E dallamtípus egy változata az F 45. szám a férfiak előadásában. Gyűjtés: Kónya Mihály (67), Csóka, 1981, Kónya S.

69 Három rózsám volt a nyáron, volt a nyáron, volt a nyáron. Leveteted mind a kilenc szoknyádat ez nóta DF]Ugrósok, csárdások, dudanóták 170. 4. EGYÉB TRÉFÁS ...adattar.vmmi.org , 10_egyeb_trefas_dalok_es_tancok,_karikazok

70 A Három szabó legénye kezdetű magyar népdalt Sándor Emma (Kodály Zoltán felesége) gyüjtötte Sümegen 1918-ban. A dal valószínűleg német eredetű.

71 kezdetű magyar népdalt Bartók Béla gyűjtötte a Pest-Pilis-SoltKiskun vármegyei Fóton 1907-ben.

72 A dal tovább élését, nagy mértékben segíti, ha valaki esetleg csak a dal cselekményére kiváncsi.

73 Kozma Dezső : Kelet felöl dörög az ég - YouTube 
Vándorcigány a legárvább széles e világon. Vagy megázik, vagy megfázik, vagy meggöthösödik, Ezt a Devla a magasból mind jó szemmel nézi. Devla, Devla, lácso Devla dikheszile reánk, Lesz-e nékünk valahára egy állandó tanyánk? Zúg a vihar, zörög az ég, jaj, de nagyon villámlik, Ez a szegény ponyvasátor egész általázik.

Benne fekszik három gádzsó, meg vagy kilenc rajkó, Belever a záporeső, mert nincs rajta ajtó. ${ }^{74}$

Nagynéném az 'Arra alá dörög az ég meg-meg villámlik' kezdetű népdalt férjétől, tanulta fiatal korában. Kis elsős gyerekként tanulta az utolsónak leírt magyar nótát, amelyet 1937-ben énekeltetett el Pintér tanító úr Csima Sándorral a kiránduláskor. Nagynéném 2020 januárjában kórházba vitele közben ezt énekelte a mentősöknek, akik Kisgyalánból Kaposvárra a kórházba érkezve, úgy nyugtattak, hogy: „A néninek nincs törése, mert végig énekelte az egész utat."

Csonka Magyarországnak a dél-keleti táján,

Csonka Magyarország dél-keleti táján,

Élt egy cigánylegény, meg egy szép cigánylány.

Zölderdő volta tanyájuk, puha pázsit fekvő ágyuk,

Zöld erdő volt a tanyája puha pázsit fekvő ágya.

Rózsalevél betakarja, hogy a szél ne járja,

Hulló levél betakarja, a hideg szél járja.

Este mikor kigyúlnak a csillagok az égen,

Cigány legény hegedűje szebben szól, mint régen, szól az erdő szélen.

Belesír az éjszakába, mesét mond a holdsugárnak, imát mond a csacska szájja.

Siratja a szeretőjét, azt a szép cigánylányt,

Imádja a mennyasszonyát, azt a szép cigánylányt.

Egyszer aztán meglátta a gróf a szép cigánylányt,

Vett is néki selyemszoknyát, aranyos topánkát.

Fényes kastélyába vitte, puha ágyába fektette,

Szerette a menyasszonyát, azt a szép cigánylányt.

Este, mikor kigyúlnak a csillagok az égen,

Cigány legény hegedűje nem úgy szól, mint régen.

A vadgalamb is azt búgja, mindig csak azt turbékolja,

Bánatában szakadt el a hegedű négy húrja.

Aztán a röntgen után mégis kiderült, hogy combcsont törése volt, melyből szerencsésen felgyógyult, sőt a mütét után még számos történetet, és dalt osztott meg velem a kórteremben is. Természetesen az itt leírtak csak töredéke annak a tudáskincsnek, amit még Csima Lajosnéval együtt elénekelhetnek. A hangsúly nem a gyüjtés mennyiségén volt, hanem azon, hogy ki, mikor, hol, miért énekelte és kitől tanulta. Igaz, a kitől tanultad? - kérdésre sokszor azt a választ kaptam, hogy: „egymástól”. Vargyas Lajos szavaival ez „a közösséghez való fordulást is jelentette". Egymástól, de a katonaságot megjárt falubelitől, a más megyéből ideköltözött

74 Kertek alatt vándorol a cigány karaván Hangzó: CD 1-23.Település, megye: Beje, Gömör Gyüjtés éve: 1958 Adatközlő: Bartók Balázsné Barci Mária , 66 éves https://docplayer.hu/19019291Meg-kell-a-buzanak-erni-valogatas-ag-tibor-korai-nepzeneigyujtesebol-iii.html Letöltés ideje: 2019.11.21. cselédlányoktól, a zalai idénymunkát végző summásoktól, vagy az 1970-es években a testvér termelőszövetkezet asszonyaitól, az egymáshoz való utazás során tanulták. A régi öregek együtt szinte kizárólag népdalt énekeltek az esküvőkön is. Aztán utat tört magának a magyar nóta, amikor a koszorús pohár körbe ment, felváltva énekelték a népdalt és a magyar nótát.

Az utolsó példán, ahol is konkrét évszám kötődik a magyar nóta megtanulásához, ez 1937 - mert, hogy kütörőt nem lát minden nap az ember - kisgyermek korban történt, amire 83 év multán is ugyanúgy emlékszik az előadó. Ez különösképpen is igazolja a gyermekkorban történő dalok tanulásának fontosságát.

Az évek múlásával más-más alkalomkor történik a dalok éneklése, például az uramat haza ne segéld, esetén, vagy akár a summásdalok nehéz fizikai munkáról számot adó, a 'Jaj, de sokat arattam a nyáron', népdalban. A szöveg modernizálódásának is tanúi lehetünk, a sátorból, szilárd építmény lesz, az 'Arra alá dörög az ég meg-meg villámlik', népdalban. Bóna Lászlóné és Csima Lajosné a katonadalok közül sokat elénekelt, ennek okát keresve rádöbbentem, hiszen ők hadiárvák. Mindkettőjük édesapja - az én nagyapám is - hadifogság következtében hunyt el. Itt is kiderült, hogy ami foglalkoztatja a gondolatainkat, arról több szót ejtünk, illetve énekelünk.

„Községeinkben asszonykórusokat alapítottak, akik többszörönként meghívják egymást, és előadásokat tartanak. Az idősebb generáció tagjait is segítségül kérik azáltal, hogy az általuk elénekelt régi népdalokat lejegyzik. (...) Az 1990-es évek végéről maradt fent színfoltként az a történet, amikor Major Jóska bácsi és Nagy Pali bácsi Kisgyalánban leült a buszmegállóba, és hosszan népballadákat énekeltek. (...) A tartalmas szórakozás lehetősége biztositva volt, és van ma is."75.

„Odafigyelve a mindennapok eseményeire, megérzi a bennük rejlö hidat múlt és jövö között, s e felismeréstől szárnyra kapva, immár tudatosan kutatni kezdi a múlt és jelen emlékeit saját magában, s a közösségben, melyben él."

„Mindenkinek szüksége van ezekre a dalokra, aki valamiféle lelki gazdaság megőrzésére igényt tart. A népi életforma teljességének szellemi mása volt a népköltészet. Töredékesen is annak egykor természetesen adott teljességéröl üzen. Sivár lelkü az, aki érzelmeit nem tudja kidalolni, méghozzá a legszélesebb skálán: a duhaj jókedvtől az unalomüző dúdoláson át a panaszos keservesig."77

„Nem ok nélkül szállnak tehát az ily remek dalok apáról fiúra. Nem ok nélkül élnek századokat, mindig új meg új nemzedékek örömének és bánatának mesteri kifejezéseként. Az ily népköltés, akárcsak az élö természet irdatlan őserdeje vagy igénytelen mezei virága, a maga természetes, egyszerü bájával, keresetlen szépségeivel minden időben legközvetlenebbül

75 Lanszkiné Széles G. 2016: 308.

$76 \mathrm{http}: / / \mathrm{csemadok}$.sk/files/2014/06/meszaros-ilonasz\%C3\%BClofalum-zsigard-2013-e-book.pdf

77 Borsi Ferenc MI VAGYUNK A RÓZSÁK Az érzékiség képi ábrázolása a magyar népdalokban 
szólt az emberi érzéshez. Bármily rohanólépésben haladjunk is (jobban mondva: haladjanak is mások) a müvelődés útján elöre, az a kor sohasem fog elkövetkezni, hogy egy rengeteg erdőnek, egy kies pataknak vagy egy virághímes rétnek látványa ne rezegtesse meg a szép iránt fogékony emberek szívét. Ellenkezőleg, csak azt jósolhatjuk, hogy a kultúrába belefáradó emberiség időnként vissza-vissza fog térni az örök természethez, az életadó, ifjító forráshoz, s így a költés terén a néphez. A népdalra mindig szükségünk lesz, mint a falat kenyérre, hogy a müköltés túlfinomult hangszerelése után a természetesség üde hangjaiban megfürödjünk s ekként a nemesebb müélvezethez való kedvünket, lelkünk egyensúlyát el ne veszítsük."78

\section{Köszönetnyilvánítás}

Hálásan köszönöm Prof. Dr. Sütő Zoltánnak részletekre is kiterjedő segítőkész javaslatait, értékes lektori munkáját.

\section{Irodalom}

EGYüd Á. 1975: Somogy néprajza I. - Somogy Megyei Múzeumok Igazgatósága, Kaposvár.

FEKETE I. 1976: Ballagó idö. - Móra Ferenc Ifjúsági Könyvkiadó, Budapest.

KATONA I. 2002: Szépen szóló madárka. - Masszi Kiadó, Budapest.

LANSZKINÉ SzÉLES G. 2007: Kisgyalán története és néprajza. Kisgyalán Községi Önkormányzat, Kaposvár.

LANSZKINÉ SzÉLES G. 2013: Fonó története és néprajza. - Fonó Községi Önkormányzat, Kaposvár.

LANSZKINÉ SzéLES G. 2016: Gölle, Kisgyalán, Fonó és Büssü települések kulturális élete a 20. században. - A Kaposvári Rippl-Rónai Múzeum Közleményei 4: 287-310.

JósA I. 2003: Sej, besoroztak. Magyar katonadalok I. - Színforrás Debrecen, Kecskemét.

\section{Internetes hivatkozások:}

Klasszikus magyar nóta | Hungarikumok Gyüjteménye ...

Vikárkutató | Vikár Béla életútja Majorné Bániczki Julianna http://www.hungarikum.hu/hu/content/kodály-módszer

Kormányzat - Agrárminisztérium - Hírek

Klasszikus magyar nóta | Hungarikumok Gyüjteménye ...

Gömöri népdalok és népballadák (könyv) - Ujváry Zoltán ...

https://en.mandadb.hu/common/file-servlet/document/661070/default/ doc_url/NA258.pdf

https://kaposvarmost.hu/videok/kaposvar-most/2014/12/08/megujult-arosseb-bakak-emlekmuve-a-szinhaz-elott_14659.html http://www.csukas.sulinet.hu/csukasmagazin/csukas-magazin $\% 20$ 2012-II-evf-01.pdf

http://somogy.hu/publikaciok/kiraly-l--peter-m-kaposvari-varoshazrarasutott.html

https://mek.oszk.hu/06600/06664/html/01.htm A magyar népköltés remekei I.

https://www.kozterkep.hu/29615/Petofi_Sandor_szobra Pozsony_1911.html

https://regi.tankonyvtar.hu/hu/tartalom/tkt/magyar-neprajzi-lexikon/ch23. htmlLetöltésPDF) Trianon traumatikus emlékezetéröl | Eva Kovacs ...ww.academia.edu > Trianon_traumatikus_emlékezetérő

http://www.nagykunreformatus.hu/content g/letoltesek/Szabone_weboldala/ballada.html

adattar.vmmi.org > fejezetek > 09 _betyardalokBETYÁRBALLADÁK (57121.)

adattar.vmmi.org , cikkek , hid_1988_10_14_czimmerDATOK KUPUSZINA NÉPRA jZAHOZ*

https://docplayer.hu/19019291-Meg-kell-a-buzanak-erni-valogatas-agtibor-korai-nepzenei-gyujtesebol-iii.html

Ugrósok, csárdások, dudanóták 170. 4. EGYÉB TRÉFÁS ...adattar. vmmi.org > 10_egyeb_trefas_dalok_es_tancok,_karikazok

https://regi.tankonyvtar.hu/hu/tartalom/tkt/magyar-neprajzi-lexikon/ ch23.html

http://csemadok.sk/files/2014/06/meszaros-ilona-sz\%C3\%BClofalumzsigard-2013-e-book.pdf 